\title{
VIROLAISEN KANSANMUSIIKIN HISTORIALLISET KERROSTUMAT JA TYYLIT
}

Virolaisesta kansanmusiikista puhuttaessa pitäisi ihan alussa huomauttaa, että meillä ei ole tapana jakaa traditionaalista musiikkiamme "primitiiviseksi" ja kansanmusiikiksi, kuten on tehty amerikkalaisessa etnomusikologiassa ja on yritetty tehdä Suomessakin. (Sitä paitsi amerikkalaiset ovat viime aikoina itsekin luopuneet tällaisesta jakomenettelystä, koska näitä käsitteitä on vaikea erottaa esim. nykymaailman perinteisestä musiikista puhuttaessa.) Käsitteellä "kansanmusiikki" tarkoitamme siis kaikenlaista traditionaalista, suullisena kommunikaationa leviävää musiikkia - osaa kansanperinteestä, folkloresta, traditionaalisesta kulttuurista, riippumatta siitä, miltä aikakaudelta se on peräisin tai millaiselle sosiaaliselle kerrostumalle se kuuluu (virolaisilla ei ole ollut omaa ylimystöä, jonka oma erilainen kulttuuri olisi erottanut muusta kansasta; rengit ja talonpojat käyttivät samaa laulu- ja musiikkikieltä).

Sanataiteesta puhuttaessa erotetaan toisistaan ns. kansanrunous ja kirjailijan itsensä muistiin merkitsemä varsinainen kirjallisuus; musiikista puhuttaessa erotetaan kansanmusiikki ns. taidemusiikista, joka leviää nuottikirjallisuuden, kuorojen, koulujen ja kirkon välityksellä tai sitten joukkoviestimien (radio, televisio, elokuva, video jne.) kautta. Tietenkin näillä on kosketuskohtia ja välimuotoja, mutta tämä on asia erikseen (Rüütel 
1989).

Virolainen kansanlaulu, kuten suomalainenkin, jakaantuu kahteen peruskerrostumaan: vanhempaan eli runolauluun (Eestissä sitä kutsutaan tavallisesti "regiärsiline rahvalaul", Suomessa "kalevalaiset laulut") sekä uudempaan eli riimilliseen kansanlauluun. Edellinen kuuluu vanhaan itämerensuomalaiseen kulttuuriin, jälkimmäinen yhdistää virolaisen kansanlaulun keski- ja pohjoiseurooppalaiseen uudempaan laulukulttuuriin. Kumpaakin luonnehtii oma musiikkityylinsä. Kummastakin voi puolestaan löytää historiallisia, alueellisia ja lajillisia erikoispiirteitä. Laulutyylin muutokset liittyvät myös muutoksiin kansansoittimissa ja soitinmusiikissa.

Vanhan ja uuden musiikkityylin ero on niin suuri, että voidaan puhua kulttuurimurroksesta, etenkin kun uudempi kansanlaulu ja musiikkityyli omaksuttiin pääpiirteissään puolessa vuosisadassa - viime vuosisadan jälkipuoliskolla (Suomessa, niin kuin tiedetään, paljon aikaisemmin). Siinä oli kyllä huomattavia alueellisia eroavuuksia. Esimerkiksi Kihnussa ja Setussa alkusoinnullinen kansanlaulu on säilynyt muiden kulttuurikerrostumien rinnalla jonkin verran nykyäänkin.

Kahden mainitun peruskerrostuman lisäksi voi erottaa vielä ns. siirtymämuotoisia tai välimuotoisia kansanlauluja, jotka sijoittuvat vanhan ja uuden kansanlaulun väliin (vaikka ne levisivät osaksi molempien rinnallakin) (Rüütel 1971). On syytä mainita myös vanhat ei-runomuotoiset lajit, jotka todennäköisesti syntyivät ennen runolaulua, mutta säilyivät runolaulun rinnalla, osaksi runolaulun kanssa muodollisesti assimiloituen ja sekoittuen. Aktuaalina pysyneen funktionsa vuoksi osa niistä on säilynyt runolauluja kauemminkin ja niitä voisi syntyä myös lisää. Musiikilliselta ilmaisultaan ne jäävät lähinnä erikoisuuksiksi ja poikkeavat sekä runolaulun että riimillisen kansanlaulun sävelmistä. Musiikista niiden tapauksessa voi tosin puhua vain sovinnaisesti. Kyseessä on pikemminkin tavallisesta puheesta poikkeava erilainen intonointi. Tällaisia ovat:

1. Huudot, huikkaukset, kutsut jne. Nämä liittyvät erilaisiin töihin, ja niillä on signalisoiva, kommunikatiivinen tai rytmiä koordinoiva funktio, sekä tapoihin ja rituaaleihin liittyvät huudot (esim. hätähuudot).

Paimenhuikkauksista ovat kehittyneet pääasiallisesti Etelä-Virossa levinneet melodiset vokaliisit - huhuilut - helletuset, aetuset jne. Ne sisältävät merkityksettömiä tavuja, refrengejä ja näiden väliin sijoitettuja etupäässä improvisoituja tekstisäkeitä (Tampere 1965:85-95; Vissel 1985; Vissel 1986). Paimenien huhuilujen perusteella voitiin identifioida henkilökin, niillä oli siis tietyssä määrin myös henkilölaulun piirteitä kuten esimerkiksi saamelaisilla joiuilla.

2. Luonnonäänien imitaatiot. Näitä ovat sekä luonnolliset (kuten met- 
sästäjien houkutusäännähdykset) että taiteellista tavoitetta omaavat imitaatiot (linnunlaulun matkimiset, rukin tai vankkurinpyörien "keskustelut" jne.) (Tampere 1958:217-220).

3. Itkuvirret. Ne ovat Eestissä säilyneet ainoastaan Setukais-alueella, joskin tietoja on kyllä muualtakin Itä-Virosta (Pino, Sarv 1981; 1982). Runolaulusta itkuvirret erottaa ennenkaikkea monitavuinen säe ja vapaarytminen melodia ja yleensä improvisaation suurempi osuus. Tositilanteessa itkuvirren esitys muuttui itkuksi. Seuraava esimerkki on ainoa itkusävelmän nuotinnus Pohjois-Virosta.

\section{Esimerkki 1.}
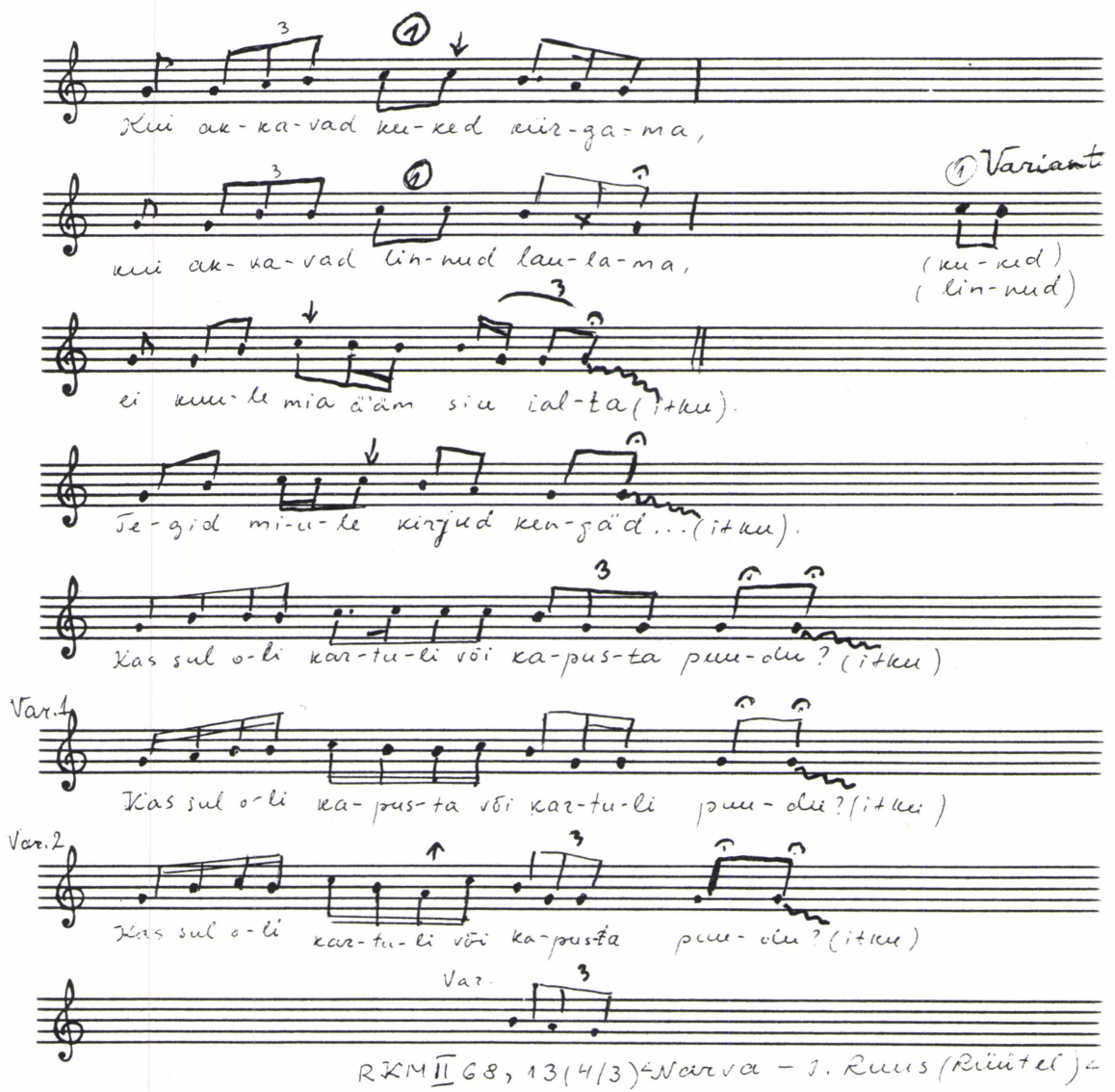

4. Loitsut. Niitä esitettiin joko pysyvässä tahtilajissa skandeeraten, huutaen tai vapaassa rytmissä resitoiden. (Tampere 1956:218; Vissel 1988:8-15).

5. Laulettavat väliosat saduissa ja muissa kertomuksissa. Näissä esiin- 
tyy sekä vapaarytmisyyttä että painollista runomittaa, viimeksi mainituissa tapauksissa sävelmissä on myös pysyvä kaksiosainen tahti. Melodian kehitys on runolauluihin verrattuna vapaampi, improvisoidumpi, lähempänä puhetta, vaikka löytyy myös vakiintuneita melodiarakenteisia sävelmiä ja enemmän tai vähemmän kalevalanmittaisia tekstejä (Salve, Sarv 1987).

6. Kehto- ja lastenlaulut. Löytyy tekstittömiä tai improvisoidulla tekstillä varustettuja tuutulauluja, joiden melodia perustuu samankaltaisten laskevien intervallien toistamiseen tai laskeviin/nouseviin hyppyihin. Osa kehtolauluista on runolauluja, ja niitä laulettiin tavallisilla runosävelmillä. Kuitenkin tällöinkin sävelmissä on usein omaperäisiä piirteitä - laajempia intervalleja sekä laajempaa improvisaatiovapautta, joka koskee myös rakennetta (se voi olla epäsäännöllinen) (Tampere 1958:161-186, Rüütel 1980:6-7). Lasten hyppy- ja leikkilauluja esitettiin vastaavien liikkeiden saatteeksi rytmisesti skandeeraamalla, usein ne päätettiin huudahdukseen tai tavalliseen puheeseen (esim. Tampere 1958:188-199).

7. Ketjulaulut. Nekään eivät Virossa tavallisesti ole puhtaasti kalevalamittaisia vaan ovat painollisessa runomitassa. Niiden esitys muistuttaa lastenlaulujen esitystä ja myös funktioltaan ne ovat muuttuneet lastenlauluiksi. Joskus niillä on runolaulujen tai uudempien laulujen melodia. Tällöin kyseessä lienee sekundaari myöhäiskehitys.

Suurin osa mainituista lajeista esiintyy myös niillä itämerensuomalaisilla, joilla runolaulu puuttuu kuten vepsäläisillä ja liiviläisillä (viimeksi mainituilta ei ole tosin tietoja itkuista). Yleensä ne kuuluvat laajalti levinneiden arkaaisten kulttuuri-ilmiöiden joukkoon. Niiden esittämisessä on paljon improvisoitua, melodisoitua puhetta tai rytmin korostamista, imitaatiota, huudahduksia. Stabiilit sävelkorkeudet ja melodian vakaa yleismuoto enimmäkseen puuttuvat, kuitenkin niiden esitys perustuu omiin traditionaalisiin käytäntöihin ja poikkeaa tavallisesta puheesta. Melodian ja rytmin vapauden rinnalla esiintyy myös rakenteellista vapautta. Tämä kaikki erottaa ne selvästi runolauluista, vaikka niissä esiintyykin runolaulujen poetiikan ja muodon keinoja ja vaikka niitä on joskus laulettu myös runosävelmillä.

Myös virolaisia runosävelmiä on usein sanottu puheenomaisiksi, ennen kaikkea niiden sävelalueen suppeuden ja puhetta muistuttavan intonaation tähden. Tietyistä melodian, rytmin sekä sävelkorkeuksien käsittelyn vapauksista ja myös varioinnista huolimatta ne kuitenkin ovat edellä käsiteltyjä ilmiöitä huomattavasti vakaamuotoisempia. Runosävelmissä erotetaan tavallisesti yksi- ja kaksisäkeisiä refrengillisiä ja refrengittömiä sävelmiä. Sävelmän pituus näyttää kaikkein varmimmin osoittavan historiallisia kerrostumia, sen lisäksi tilastollisesti yleisenä kehityssuuntana muodolliseen 
kehitykseen liittyy sävelalueen laajeneminen (Taul.1).

\begin{tabular}{c|c|c}
\multicolumn{2}{c}{ Diapasooni (sävelalue) } \\
\cline { 2 - 3 } Melodian pituus & kvartti & kvintti ja laajempi \\
\hline 1-säkeiset & $78 \%$ & $22 \%$ \\
2-säkeiset & $32 \%$ & $68 \%$ \\
Pidemmät & $14 \%$ & $86 \%$
\end{tabular}

\section{Taulukko 1.}

Yksisäkeiset refrengittömät, ambitukseltaan tavallisesti terssin tai kvartin laajuiset sävelmät muodostavat virolaisen ja luultavasti yleensä itämerensuomalaisen runolaulun vanhimman sävelmäkerrostuman. Niillä on vastineita myös muun suomalais-ugrilaisen musiikin vanhimmissa kerrostumissa. Sellaisia sävelmiä on merkitty muistiin pääasiallisesti Pohjois- ja LänsiVirosta sekä saarilta. Sävelmien levinneisyysalue on pääpiirteittäin sama kuin virolaisen runolaulutradition keskeinen alue. Runolaulu esiintyy siellä kaikkein klassisimmassa muodossaan, ja tutkijoiden mielestä sieltä ovat peräisin monet vanhimmat runolaulut (kertovat, elonkorjuulaulut, vanhimmat maatalouskalenteritapoihin liittyvät seremonialaulut jne.). Se on lähinnä myös Viron vanhinta maanviljelyaluetta. Tällaiset sävelmät voidaan erottaa kahdeksi ryhmäksi (kummassakin löytyy vielä monia alatyyppejä). Eri laululajeissa käytössä olevat puheenomaiset sävelkuviot ovat hyvin samanlaisia koko levinneisyysalueellaan, niillä on yhteinen tukisävelten systeemi ja rakenne, joka on sukua puheintonaatiolle (Rüütel 1986:159176). Näiden sävelmien levinneisyysalue ulottuu Virumaalta Kuusaluun ja Jǒelähtmeen, ja sieltä eteenpäin toisaalta Kodavereen, toisaalta Pärnun joen vesistön kautta Lounais-Viroon - Pärnumaan ja Läänemaan eteläosan rannikolle sekä Muhuun ja Itä-Saarenmaalle (Rüütel 1986). Tämä alue on suurin piirtein sama kuin nuoremman pronssiajan lopun ja varhaisemman rauta-ajan arkeologinen kulttuurialue, jolla on monia olennaisia taloudellisia ja kulttuurillisia yhteispiirteitä: maanviljelyn muuttuminen keskeiseksi elinkeinoksi, hiidenkiuasten ja kulttikivien leviäminen jne. Tämä aikakausi on samalla itämerensuomalaisen kauden loppuvaihetta, jolloin itämerensuomalaiset eivät siis vielä olleet eronneet eri kansoiksi ja puhuivat itämerensuomalaista kantakieltä. Juuri tähän aikaan voi sijoittaa kalevalanmittaisen runolaulun synnyn. Näin kaukaisia aikoja koskevat päätelmät ovat tietysti vain oletuksia, mutta on todennäköistä, että runolaulu on syntynyt juuri tämänkaltaisista sävelmistä. Tällaisista sävelmistä on tehty lähes identtisiä muistiinpanoja 1800-luvun alusta meidän vuosisatamme viimei- 
siin vuosikymmeniin saakka. Tiedämme, millaiset suunnattomat muutokset ovat tapahtuneet tämän aikajakson yhteiskunnallis-taloudellisessa elämässä ja kulttuurissa. Kokonaan uusia musiikkivirtauksia on välillä syntynyt ja kadonnut. Kun arkaaiset kansansävelmät jäivät näissä muutoksissa ennalleen, voi siten olettaa, että ne pysyivät verrattain muuttumattomina myös aikaisemmin, kun elämäntavassa ei tapahtunut suuria muutoksia. Arkaaisten musiikki-ilmiöiden poikkeuksellisen konservatiivisuuden ovat panneet merkille myös muiden kansojen musiikintutkijat. Tällaisia lauluja esittivät tavallisesti esilaulaja ja jokaista hänen laulamaansa säettä toistava kuoro (kuoron saattaa korvata yksi laulaja), kuoro tulee mukaan esilaulusäkeen viimeisillä tavuilla (tekee "liegajuksen"), myös esilaulaja liittyy kuoroon sen esityksen lopussa. Tällainen laulutapa näyttää olleen yleinen koko Viron alueella, ainakin vanhoissa rituaalisissa lauluissa (esim. seuraavassa häälaulussa), mutta myös kertovissa runolauluissa, kuten eri paikkakuntien muistiinpanot osoittavat. Kiinnittäisin huomionne vielä siihen, että laulussa esiintyviä murrelmasäkeitä ei skandeerata, vaan niissä merkitään sanapainot kielenomaisesti pehmeällä aksentilla. Tällainen esitystapa on k.o. sävelmissä vallitsevana (Esim. 2).

\section{Esimerkki 2.}

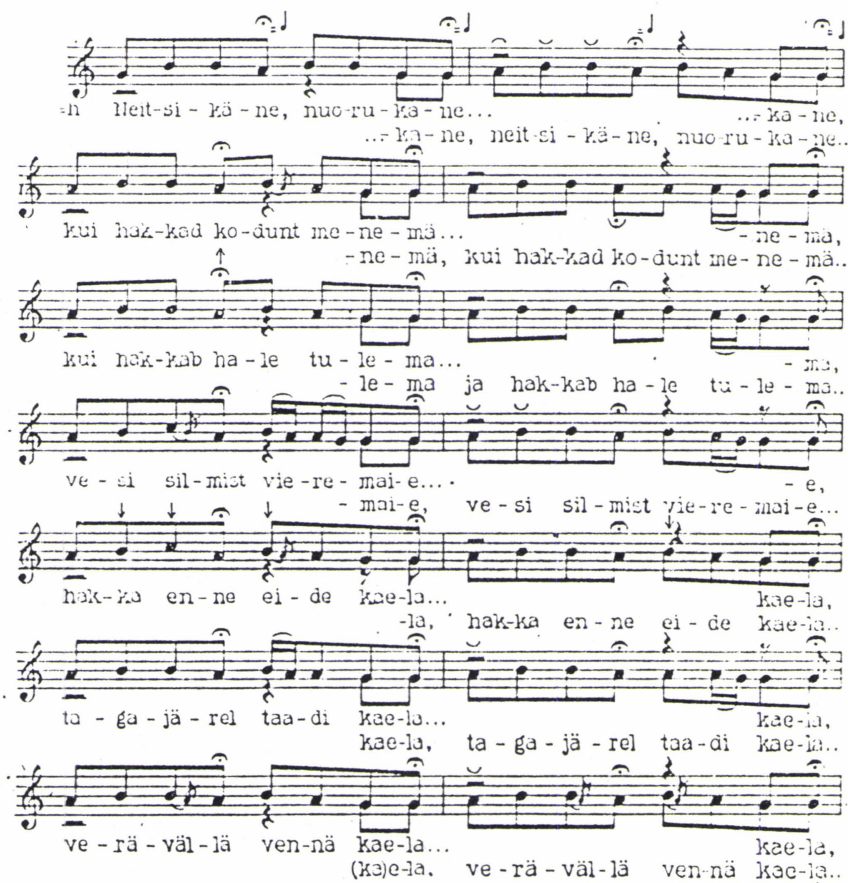




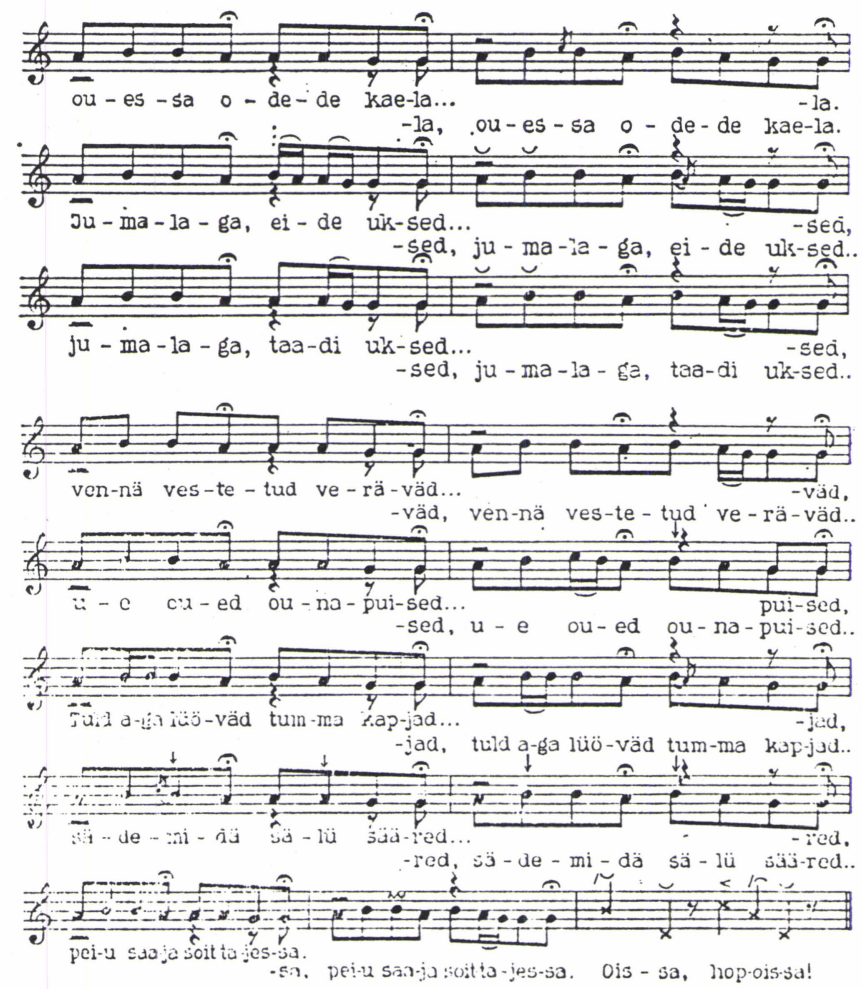

Rytmityyppejä on monta. Länsi-Virossa pidennetään tavallisesti säkeen loppunuottia, idempänä useammin jokaista tavunuottia (Rüütel 1986:243). Pääasiallisesti Järvamaalla ja sen naapurialueilla on viimeksi mainitun rytmityypin pohjalta kehittynyt monenlaisia ns. keinurytmejä (Tampere 1960:128-130). Näitä lauluja laulettiin keinuttaessa. Se oli ennenvanhaan rituaalinen, maagista merkitystä omaava toiminta, myöhemmin siitä tuli tavallinen nuorten kanssakäymisen muoto ja ajanviettotapa.

Keinulaulujen melodia kuten rytmikin poikkeaa käsitellyistä puheenläheisistä polyfunktionaalisista sävelmistä. Siinä on useita melismoja, joskus melodialinja on laskeutuva-nouseva. Vaikka tällaisten sävelmien levinneisyysalue ja käyttöpiiri on huomattavasti suppeampi, on erilaisia melodiatyyppejä huomattavasti enemmän. Näiden sävelmien synty liittyy toisaalta esitystapaan ja laululajiin, toisaalta alueellisten kulttuuridialektien kehittymiseen. Myös puheenläheisistä sävelmistä kehittyi paikkakunnallisia erikoismuotoja. Nämä murteet kehittyivät II-IV vuosisadalla, kuten arkeologit ja kielentutkija ovat osoittaneet.

Etelä-Virolaisille työ- ja merkkipäivälauluille sekä leikkilauluille ovat luonteenomaisia lyhyet 1-2-sanaiset refrengit jokaisen säkeen jäljessä 
(Tampere 1956:173-176; Tampere 1960:79-84 jne.). Kertosana on jokaisessa laululajissa erilainen. Tällainen rakennetyyppi on tunnusomainen myös balttilaisten ja slaavilaisten kansojen vanhoille merkkipäivälauluille. Virossa se on ilmeinen balttilainen laina: se esiintyy vain Etelä-Virossa, sitä ei löydy Inkeristäkään. Etelä-Virossa ja Pohjois-Latviassa esiintyy myös useita yhteisiä tai läheisiä sävelmiä. Ne ovat ilmeisesti syntyneet kahden kulttuurin symbioosin tuloksena.

Valtaosa virolaisista runosävelmistä on kaksisäkeisiä pentakordi- tai heksakordisävelmiä ilman refrengiä, jollaisia ovat myös suomalaiset ja karjalaiset kalevalasävelmät. Ne poikkeavat kalevalasävelmistä pääasiassa rytmin suhteen - viisi-iskuinen ns. kalevalarytmi kahdella pitkällä nuotilla säkeen lopussa ei ole luonteenomaista virolaisille kansanlauluille, kuten ei Kalevala-aiheinen sankariepiikkakaan. Tavallinen rytmi on 8/8 (kahdeksan tasapitkää nuottia); harvemmin voi tavata muita yksisäkeisille sävelmille luonteenomaisia rytmejä (joissa on pidennetty loppunuotti tai jokainen painoton nuotti tai keinurytmi). Ennenkaikkea miesten lauluissa voi esiintyä jokaisen painollisen nuotin pidentämistä, sen tuloksena syntyy triolinen rytmi $\left(\delta_{3} \cdot \delta_{3} \cdot\right.$ jne.), joka laulun edetessä voi vaihdella yhtäläisen kahdeksaniskuisen rytmin kanssa. Melko tavallista on (sekä yksi- että kaksisäkeisissä sävelmissä), että nuottien todelliset pituudet ovat laulamisen aikana riippuvaisia tavun pituudesta - lyhyet tavut ovat lyhyempiä, pitkät taas normaalikestoa pidempiä. Murrelmasäkeessä esiintyy kaksisäkeisissä sävelmissä sekä skandeeraamista - yhtäläistä, pysyvää tahtimittaa - että sanapainojen korostamista ja siitä johtuvaa vaihtelevaa tahtilajia. Viimeksi mainittuun esitystapaan liittyvät usein myös melodian modifikaatiot (Esim. 3).

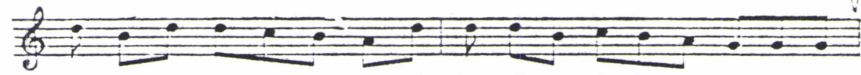

Sie nei-du i - se-gi jol-li, kes lä-heb rio!-ka-ie me-he-ie
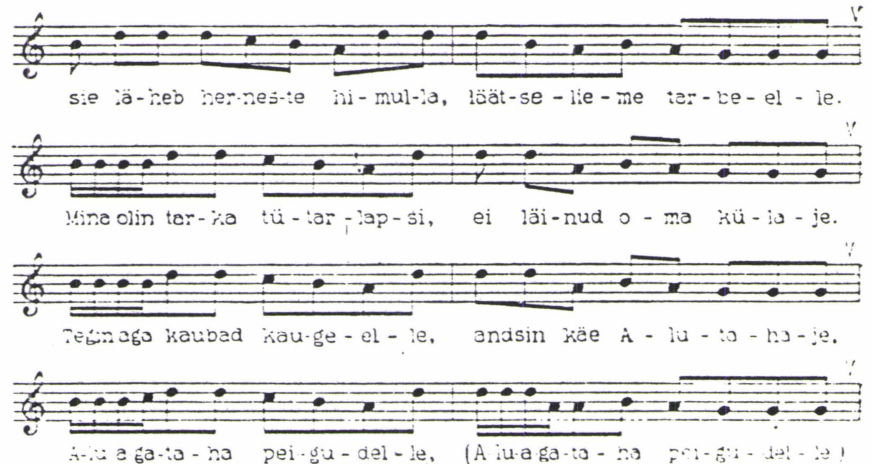


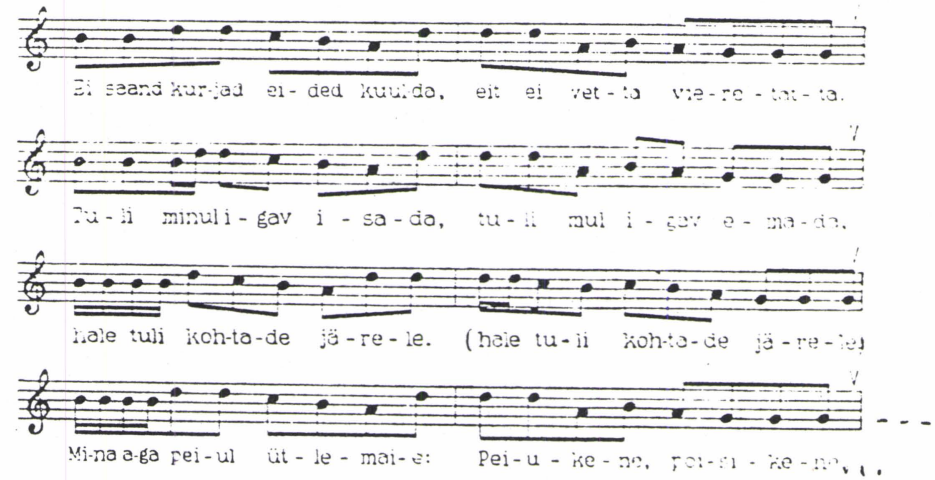

Esimerkki 3. ("Lahemaa vanad laulud", s. 156)

Tässä sävelkerrostumassa on melko runsaasti erilaisia melodiatyyppejä, joiden levinneisyys on enemmän alueellista kuin konkreettisiin laululajeihin liittyvää, vaikka tiettyjä tilastollisia tendenssejä voi huomata myös niiden suhteissa laululajeihin. On myös melodiatyyppejä, jotka tunnetaan aika laajalla alueella. Tähän kuuluu esim. ns. kalevalasävelmän melodiamalli, jossa ensimmäinen säe on ulottuvuudeltaan kvintti (pentakordi) ja joka loppuu toiselle asteikolle; toinen säe kvartti, joka loppuu perussäveleen. Tällainen melodiamalli löytyy monilta kansoilta, mm. kaikilta suomalais-ugrilaisilta. S. Szomjas-Schiffertin teorian mukaan se onkin perussuomalais-ugrilainen. Erään toisen teorian mukaan tällainen rakennetyyppi on lähtöisin Lähi-Idän maista. Siellä se on kehittynyt säkeistömallin mukaan, joka koostuu kahdesta yhtä pitkästä symmetrisestä säeparista, joita yhdistää loppusointu. Tällainen säkeistö (kreikkalainen distihon) kehittyi muinais-arabialaisessa runoudessa viimeistään IV vuosisadalla j.Kr. ja on myöhemmin, varhais-islamin kaudella tullut tunnetuksi kassidi-nimityksenä (Michaelides 1987). Eurooppalaiseen musiikkiin tällainen runo- ja sävelmuoto on luultavasti tullut keskiaikaisen arabialaisen musiikin välityksellä.

Mitä kalevalasävelmiin ja näille tyylillisesti ja typologisesti läheisiin virolaisiin kaksisäkeisiin runosävelmiin tulee, niin ne eivät ole sidottuja toisiinsa loppusoinnullisen säeparin avulla kuten eurooppalaisessa ja LähiIdän runoudessa on tapana vaan runosävelmälle tyypillisellä säekertauksella (esilaulajan säkeen toistaa kuoro tai toinen laulaja). Kyseinen musiikillinen rakenne perustuu runolaulun erikoisuuksiin ja vastaa runon säeparille luonteenomaista puheintonaatiota. Typologisesti se on sukua vanhemmille 
puheenomaisille sävelmille ja on ilmeisesti kehittynyt itämerensuomalaisten keskuudessa, vaikka tämän sävelmäkerrostuman muutamien alatyyppien muodostumisessa voivat tulla kyseeseen jotkut länsi- ja etelänpuoleiset vaikutukset. Koska nämä melodiat ovat hyvin samankaltaisia kuin ns. kalevalaisissa lauluissa, niiden kehitys ja leviäminen voidaan ajoittaa varhaisfeodaaliseen karjalaisen kulttuurin kukoistuskauteen (1200-1400-luku).

Pääasiallisesti Kaakkois-Virossa esiintyy yksi- tai kaksisäkeisiä (AA1rakenteisia) sävelmiä, jotka ovat luonteeltaan myös vanhakantaisia, mutta poikkeavat pohjois- ja länsi-virolaisista sävelmistä rytmiltään, melodialtaan ja/tai rakenteeltaan (fraasien nousevat loput tai muut puheintonaatiosta poikkeavat sävelkorkeuden nousut, rytmit d d d (गJ) d d d d ;

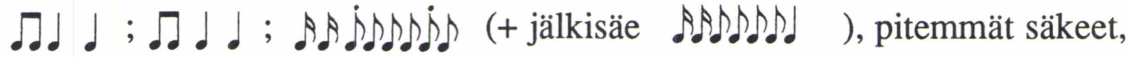
joihin liittyy runsaasti sanantoistoja jne.). Ne poikkeavat jossain määrin sekä kalevalamittaisen runolaulun säerakenteesta että puheintonaatiosta. Myös setukaisalueella ja Inkerissä (inkeroisilla ja vatjalaisilla) on runsaasti vastaavanlaisia sävelmiä, ja niiden levinneisyyden voi ehkä selittää itäbalttilaisella substraatilla (entisillä itä-balttilaisten alueilla asuvilla latvialaisilla, liettualaisilla ja itä-slaavilaisillakin esiintyy samankaltaisia piirteitä). Itä-balttilaiset siirtyivät naapuruuteemme I vuosituhannen keskipaikkeilla j.Kr.

Kaakkois-Virossa tapaa myös vanhakantaisia borduna-sävelmiä. Kyseessä on tavallisesti joka tavussa toistuva melodisoitu urkupiste (esimerkki 4). Bordunaa esiintyy myös latvialaisilla, mutta Latviassa dominoiva ns. säkkipilliborduna poikkeaa kuitenkin kaakkois-virolaisesta. Kaakkois-virolainen borduna on ehkä lähempänä mordvalaista urkupistetyyliä, mutta samankaltainen borduna tunnetaan myös Länsi- ja Valko-Venäjällä. Borduna-sävelmien leviämistä Latviassa on pidetty itä-balttilaisena kulttuurisubstraattina (Boiko 1989).

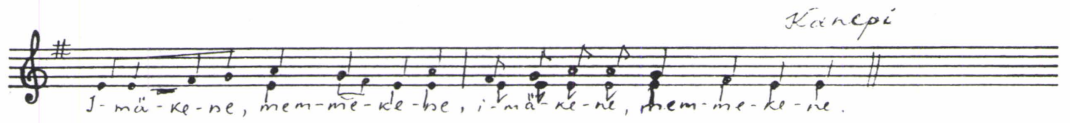

\section{Esimerkki 4.}

Setukaisten laulutyyli poikkeaa muusta virolaisesta kansanlaulusta omalaatuisella moniäänisyydellä, joka muistuttaa mordvalaista kansanlaulua (Rüütel 1990). Etelä-Viron, etenkin Kaakkois-Viron lyyrisissä ja lyyriseeppisissä lauluissa esiintyy pitkiä refrengejä sisältäviä tai säeosien toistoihin liittyviä laajemman muotoisia sävelmiä. Myös melodiikaltaan ne ovat monimutkaisempia ja edustavat ilmeisesti uudempaa musiikkityyliä. Näissä sävelmissä (myös refrengisanoissa) voi huomata slaavilaisten kansojen kulttuurivaikutusta (Esim 5.). 


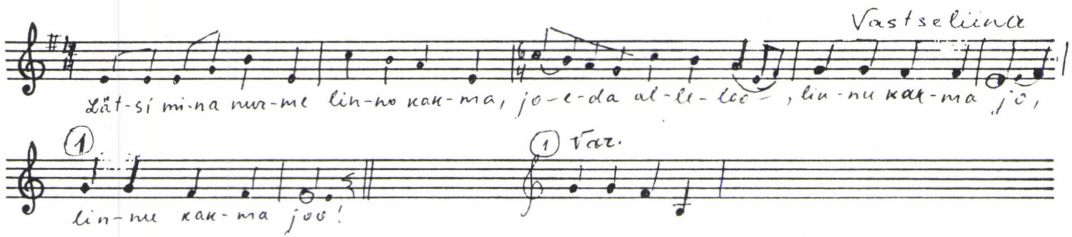

\section{Esimerkki 5.}

Viimeinen kaakkois-virolainen refrengilaulu (esimerkki 11) edustaa oikeastaan siirtymämuotoista kansanlaulua, jossa runolaulun tunnukset (alliteraatio, parallelismi, kvantitatiivinen kalevalamitta eivät enää esiinny johdonmukaisesti ja refrengi sekä sanatoistot jakavat laulun säkeistöiksi, joka nähtiin myös viimeisestä esimerkistä). Mainittakoon, että termi "siirtymämuotoinen" tai "välimuotoinen" on sovinnainen, ja se tarkoittaa erilaisia muotoja, jotka ovat syntyneet myöhemmin kuin runolaulu ja aikaisemmin kuin riimillinen kansanlaulu (vaikka nämä laulut elivät osaksi samanaikaisesti), joissa esiintyy molemman laulumuodon tunnuksia tai joista puuttuvat kummankin laulumuodon tunnusomaiset piirteet.

Alliteraation, parallelismin, loppusoinnun, stroofirakenteen ja runomitan esiintymistaajuuden ja erikoispiirteiden pohjalta välimuotoiset kansanlaulut voi jakaa viiteen muototyyppiin (niiden erikoispiirteiden oleellisuutta on todistettu matemaattisessa tilastotieteessä tunnetun ns. Studentin testin avulla - Rüütel 1969; Rüütel 1971: 85-93).

Havaitut muototyypit ovat tietyssä korrelaatiossa musiikillisten tunnusten ja laululajien kanssa, vaikka viimeksimainittujen rajat eivät yhdy (Taul. 2).

\begin{tabular}{|c|c|c|c|c|c|}
\hline Laululaji & I & II & III & IV & $\mathrm{v}$ \\
\hline Tanssilaulut & & $m$ & & & \\
\hline Laululeikit & & & 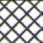 & & \\
\hline Rekryyttilaulut & & & & & \\
\hline Kylälaulut & & & & & \\
\hline $\begin{array}{l}\text { Balladit ja } \\
\text { sentiment. laulut }\end{array}$ & & & & & \\
\hline
\end{tabular}

Taulukko 2.

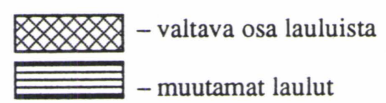

Ensimmäinen muototyyppi esiintyy lähinnä miesten lauluissa - humoristisissa kylälauluissa ja rekryyttilauluissa, vähemmän balladeissa. Se on vielä 
lähellä runolaulumuotoa ja syntynyt sen kehityksen tuloksena. Lauluja esitettiin tavallisesti kaksisäkeisinä, kaksiosaisessa tahtilajisssa pentakordi- tai hektakordisävelminä. Vauhdikaat miestensävelmät ovat vallitsevia. Typologisesti ne ovat usein sukua toisen muototyypin tanssilaulusävelmille, poiketen niistä etupäässä tahtilajiltaan.

On myös lyyrisiä ja luonteeltaan kertovia sävelmiä, jotka eivät poikkea tavallisista runosävelmistä. Etelä-Virossa löytyy saman muototyypin lauluista lyyrisiä refrengisävelmiä (Esim. 5), joilla on monimutkaisempi rakenne.

Toinen välimuotoinen laulutyyppi poikkeaa ensimmäisestä pääasiassa kolmijakoisen tahtilajinsa vuoksi. Tahtilaji on lainattu säkkipillisävelmistä, joista nämä tanssilaulusävelmät ovat lähteneet. Muototyyppi on kehittynyt runosäkeitä ja säkkipillisävelmien kolmijakoista tahtilajia toisiinsa sovittamalla (Rüütel 1971). Normaalisäe koostuu kahdesta daktyylistä, mutta usein esiintyy lisätavuja (erityisesti säkeen alussa) ja runojalkoja, joista puuttuu lopputavu (erityisesti säkeen lopussa). Tuloksena on kuusi tai viisi painoa ja vaihtelevan lukumäärän painollisia tavuja sisältävä säe, jonka rytmi vaihtelee, mutta sävelmän tahtilaji on pysyvästi kolmijakoinen. Esiintyy myös lauluja, jotka perustuvat kolmeen daktyyliin ja jonka musiikillinen säe on vastaavasti kolmitahtinen.

Säkkipillisävelmiin verrattuna (niistähän tällaiset sävelmät ovat peräisin), ovat laulujen melodiat yksinkertaistuneet: monimutkaisemman muotoisesta pillisävelmästä otetaan tavallisesti vain yksi osa sekä jätetään pois melodiset koristeet ja kaavamaistetaan melodiaa ja rytmiä (Esim. 6).

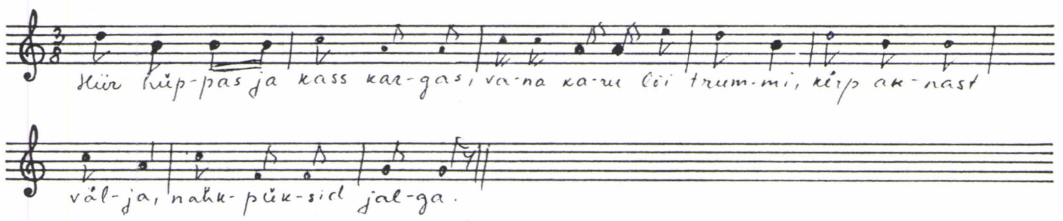

Esimerkki 6.

Kolmas muototyyppi esiintyy ainoastaan leikkilauluissa. Niitä esiintyy monissa maissa, ja Viroon ne ovat tulleet ruotsalaisilta, suomalaisilta, saksalaisilta ja latvialaisilta (Rüütel 1980 A). Muototyyppi poikkeaa muista ennenkaikkea säkeistörakenteiltaan. Ne ovat erikoisia ja perustuvat sanatai säetoistoihin ja refrengeihin. Esiintyy monenlaisia rakenteita, runomittoja ja sävelrytmejä, joista useita löytyy ainoastaan III välimuototyypistä. Loppusointu ja parallelismi tavallisesti puuttuvat, alliteraatiota on vähemmän kuin I ja II muototyypissä. Käännöslainalliset tekstit ovat paikan päällä usein liittyneet alkuperäisiin melodioihin, jotka ovat tavallisesti runosä- 
velmien tapaan puheenomaisia, niiden ulottuvuus on suppea (terssi, kvartti), mutta ne poikkeavat vanhoista runosävelmistä juuri säkeistörakenteeltaan ja rytmeiltään (Rüütel 1980 A:39-50; 146-149 jne.).

Neljännelle muototyypille on luonteenomaista sekä alliteraatio, parallelismi että loppusoinnun puuttuminen. Runomitta on eri lauluissa erilainen, ja löytyy myös vapaamuotoisia lauluja. Usein esiintyy jambi, jota ei edellisistä muototyypeistä löytynyt. Tämä tyyppi liittyy leikki- ja sotilaslauluihin, mutta varsinkin sentimentaalisiin lauluihin ja balladeihin, jotka enimmäkseen ovat saksalaista alkuperää.

IV muototyypin sävelmien perusrakenne oli useimmiten nelisävelinen säkeistö (stroofirakenteet $\mathrm{ABAB}, \mathrm{ABCD}, \mathrm{ABCB}$ jne.) ja ne ovat laaja-alaisia (oktaavi ja enemmän) duuri- tai mollisävelmiä.

Sotilaslaulusta ja balladeista löytyy myös luonteeltaan arkaaisempia sävelmiä (Esim. 7).

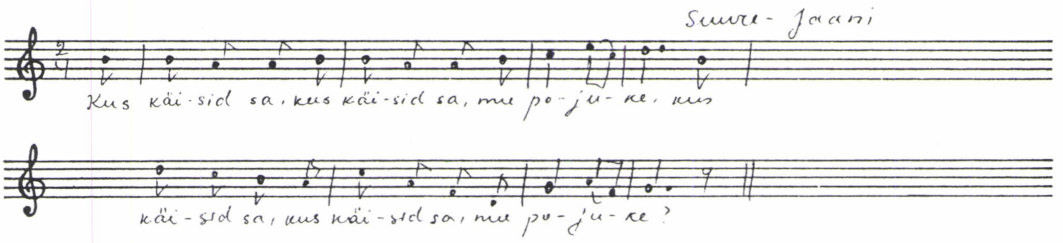

Esimerkki 7.

IV muototyyppiin kuuluvat myös jotkut vapaamittaiset, hengelliset runot, jotka eivät jakaannu säkeistöihin ja joita resitoitiin ilman sävelmää tai laulettiin monotonisina resitatiivisina sävelminä. On myös säkeistöllisiä hengellisiä tai raamatunaiheisia lauluja, lähinnä Etelä-Virossa. Ne kaikki poikkeavat täydellisesti kirkollisista koraaleista, jotka levisivät virsikirjojen kautta (Esim. 8).

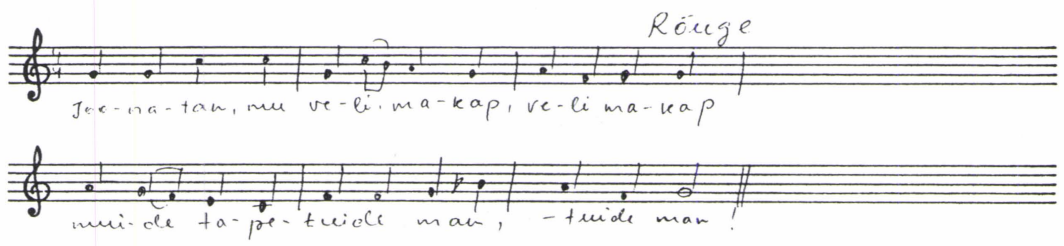

\section{Esimerkki 8.}

V muototyypin luonteenomaisina piirteinä ovat säännöllisen loppusoinnun ja alliteraation esiintyminen rinnakkain. Parallelismi on sporadista. Stroofit perustuvat säepariin, jotka voivat järjestäytyä myös 4-säkeisiksi stroofeiksi (esim. ABAB). Runomitta perustuu 4-polviseen painolliseen trokeeseen. Muototyyppi esiintyy pääasiallisesti kylälauluissa (harvemmin leikkilauluissa). Se on muodostunut alkusoinnullisten runolaulujen ja tai- 
derunouden muotopiirteiden sekoittumisen tuloksena).

Uudemman kansanlaulun syntymiseen on siis monia syitä ja lähteitä. Sen muodostumisprosessi on pitkä ja monisärmäinen. Herrnhutilaisuus ja virret, joita on pidetty uudemman kansanlaulun syntymisen päätekijöinä, kyllä myötävaikuttivat vanhan kansanlaulun vähenemisen ja riimiin ja uudenlaisen harmonian leviämiseen, mutteivät samalla olleet mikään olennainen lähde uudemmalle kansanmusiikille. Jos loppusoinnullisen laulumuodon keskeisenä esikuvana oli taidemusiikki ja kirjallisuus, ei samaa voi sanoa siirtymämuotoisesta laulukerrostumasta. Se on muodostunut suullisena traditiona pääasiallisesti ilman kirjallisuuden esikuvia.

Erittäin huomattavana tekijänä sekä siirtymämuotoisen että loppusoinnullisen kansanlaulun kehittymisessä oli naapurikansojen kansanlaulu. Olennainen osa oli myös soitinmusiikilla (aikaisemmin säkkipilli, myöhemmin viulu- ja hanurisävelmät). On merkittävä, että huomattavat muutokset tapahtuivat itse alkusoinnullisessa kansanlaulussa. Ei ole epäilystä, etteikö näillä muutoksilla olisi ollut osuutensa uudempien virolaisten laulutyylien kehittymisessä. Nämä muutokset johtuivat sekä kielen kehityksestä (sanojen lyhentyminen, vanhojen kieliopillisten rakenteiden katoaminen jne.) että uuden aikakauden sosiaalipsykologisista muutoksista, jotka vaativat tunteiden aktiivisempaa ilmaisemista ja tapahtumien välittömämpää heijastamista. Viimeksi mainitut tendenssit liittyivät laajalti miesten merkityksen lisääntymiseen virolaisessa kansanlaulutraditiossa.

Uudempi kansanlaulu syntyi kaikkien näiden tekijöiden yhteisvaikutuksen tuloksena.

Riimillisissä lauluissa dominoivat nelisäkeiset, ulottuvuudeltaan laajat duuri-, ja harvemmin mollisävelmät. Voi erottaa seuraavia sävelmätyyppejä:

1. Humorististen miestenlaulujen sävelmät, joissa puolestaan voi erottaa (a) kertomuksellisia sävelmiä, jotka seuraavat alkusoinnullisten miestenlaulujen traditiota ja (b) soitinsävelmistä lainattuja tanssisävelmiä (pääasiallisesti polkkakappaleet). On myös välimuotoja. Esimerkiksi myös polkkakappale voi olla sovitettu sävelmäksi (Esim. 9A ja B).

Esimerkit 9 A, B.

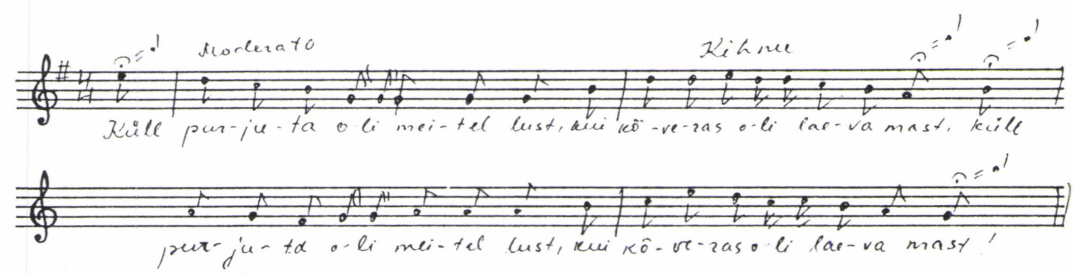




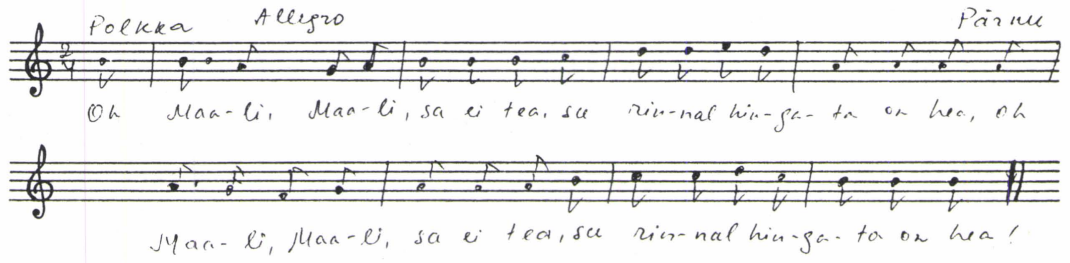

2. Pääasiallisesti Etelä-Virossa tunnetut refrengilliset sävelmät, jossa refrengi kuuluu perussävelmään. $\mathrm{Ne}$ ovat luonteenomaisia piirileikeille ja humoristisille kylälauluille (esim. Rüütel 1983:29-67, 93-111, 128-150 jne.).

3. Pääasiallisesti saksalaisilta lainatut tai saksalaisten sävelmien mallin mukaan luodut sentimentaaliset laulu- ja balladisävelmät, joille on tunnusomaista laaja ambitus, intervallihypyt ja kiemurteleva melodia, pisteelliset rytmit jne. (Esim. $10 \mathrm{~A}$ ).

Esimerkki $10 \mathrm{~A}$.

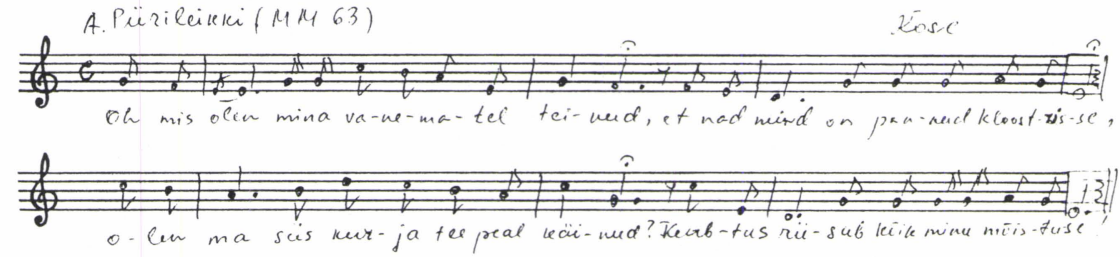

4. Uudemmat tanssilaulut (polkat, valssit, reinlenterit, jne. vrt. esim 9B; esim. 10 B).

Esimerkki $10 \mathrm{~B}$.

B.Valitanssif MM 84)

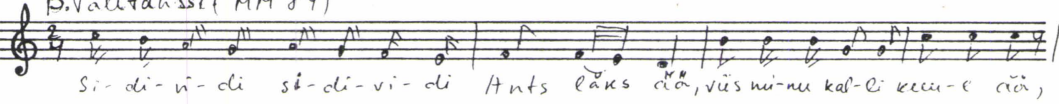

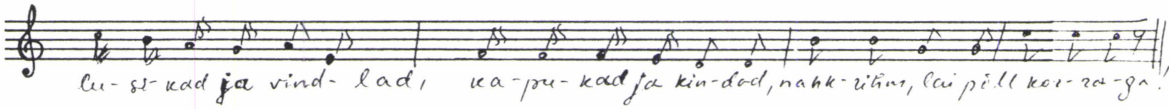

5. Piirileikit, joissa on välitansseja ja joissa sentimentaalisten laulujen (harvemmin 8. ryhmän) sävelmät ja tanssilaulut liittyvät toisiinsa (viimeiset sijoitettiin jokaisen esilaulun väliin ja niiden säestyksellä tanssittiin piirin keskellä polkkaa, valssia, reinlanderia jne. (Rüütel 1983:349-413) (Esim. 10).

6. Lyyriset pääasiallisesti sota- ja sotilaslaulujen, harvemmin muut miesten laulujen sävelmät, jotka poikkeavat humorististen miestenlaulujen sävelmistä elegisemman mielialan ja lyyrisemmän itseilmaisun puolesta, sentimentaalisten laulujen sävelmistä taas raikkaamman ja hillitymmän ilmaisun puolesta (Esim. 11). 
Esimerkki 11.

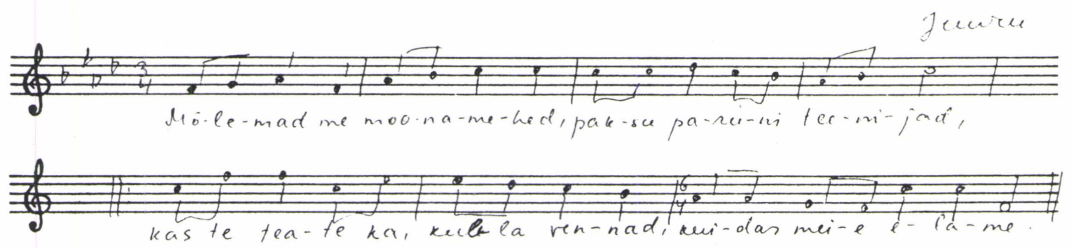

Yhdessä artikkelissa ei tietenkään ole mahdollista kuvata perusteellisesti kaikkia virolaisen kansanmusiikin alueellisia ja lajillisia erikoisuuksia. Tässä yritimme tuoda esiin vain keskeisiä historiallisia kerrostumia ja musiikkityylejä. Kiinnittäisin huomiotanne vielä siihen, että yllämainittujen lähteiden lisäksi on virolaisia kansanlaulunäytteitä myös kuultavilla melko laajoissa tieteellisissä äänilevyantologioissa. V?nhan runolaulun eri lajeista saa hyvän yleiskuvan H. ja L. Tamperen kokoamasta viisi levyä sisältävästä sarjasta "Eesti rahvalaule ja pillilugusid I", uudemmista laululajeista taas allekirjoittaneen kokoamasta kolmen levyn sarjasta "Eesti rahvalaule ja pillilugusid" II (samaan sarjaan kuuluu kaksi H. Tamperen kokoamaa soitinmusiikkilevyä). Virolaisten runolaulujen paikkakunnallisista tyyleistä löytyy runsaasti esimerkkejä kahdessa allekirjoittaneen kokoamassa levyssä "Eesti rahvamuusika antoloogia".

\section{Lähteet}

Boiko, M.

1989 "New Concepts in Ethnogenesis of Baltic Peoples and Ethnomusicology." - International Conference Folk Music Today. Tallinn, July 10-13, 1989. Abstracts, Tallinn.

Mirov, R., Rüütel, I., Tormis, V.

1977 Lahemaa vanad laulud. Tallinn.

Pino, Veera, Sarv, Vaike 1981-1982

Setu surnuitkud I-II. Tallinn.

Rüütel, Ingrid

1969 Eesti uuema rahvalaulu kujunemine. Dissertatsioon filoloogiakadidaadi teadusliku kraadi saamiseks. Tartu.

1971 Eesti unema rahvalaulu varasemast srengujärgust. - Paar sammukest eesti kirjanduse uurimise teed. VII. Tartu.

1980 Mustjala regiviiside tüpoloogia. Tallinn.

1980A Eesti uuemad laulumängud I. Tallinn. 
1983 Eesti uuemad laulumängud I. Tallinn.

1986 Олнострочные узкооо́ьемные свадео́ные налевы в оо́щем контексте зстонских рунических песен. - Музьпка в свадео́ном оо́ряде финно-угров и соседних народов. Таллин.

1986А Тилология, структура и развитие эстонских односториных свадео́ных налевов - Музька в обрядх и. трудовой деятельности финно-угров. Таллин.

1989 "Folklore Today: Some Theoretical Aspects." - International Conference Folk Music Today. Tallinn, July 10-13, 1989. Tallinn. Abstracts.

1990 "Die Schichten des Volkslieds der Setukesen und ihre ethnokulturellen Hintergründe." - Finnisch-ugrische Forschungen XLIX. Helsinki.

Salve, Kristi, Sarv, Vaike

1987 Setu laulud ja muinasjutud. Tallinn.

Szmojas-Schiffert, Gy.

1965 "Der Kalevala-Typ in den gemeinsamen Melodien der finnougrischen Völker." - Congressus Secundus Internationalis Fenno-Ugristarun, Helsinki.

Tampere, Herbert

1956 Eesti rahvalaule viisidega I. Tallinn.

1958 Eesti rahvalaule viisidega III. Tallinn.

1960 Eesti rahvalaule viisidega II. Tallinn.

Vissel, Anu

1985 "Lóuna-Eesti ja lätikarjaselaulude ühisjooni." -

Nooredfiloloogias 1985. Noordteadlaste XII konverents 22. mail. Teesid. Tallinn.

1988 Eesti karjaselaulud II. Vórumaa ja Tartumaa karjaslaulud. Tallinn. 